\title{
Unilateral Trade Sanctions as a Means to Combat Human Rights Abuses: Legal and Factual Appraisal
}

\begin{abstract}
Some developed countries have used unilateral trade sanctions against governments that have allegedly been engaged in gross violations of human rights as a tool to force such governments to comply with basic human rights standards. Even though unilateral trade sanctions might be targeted against governments that grossly violate human rights, such measures have unintended consequences on the general population who live in the target country. In many cases, the general population suffers as a result of such sanctions rather than the public officials who are the targets. Hence, the effectiveness of such measures in meeting the desired result is questionable. Such measures have been utilized by countries that are members of the World Trade Organization (WTO) thereby raising the issue of the legality of such measures under the WTO rules. The two main issues that surround unilateral trade sanctions are thus the legality of such measures under the WTO rules and the effectiveness of the measures to meet the desired result. I argue that unilateral trade sanctions on grounds of human rights violations are neither permissible under the WTO rules nor effective weapons to achieve the goals (i.e. forcing governments to comply with basic human rights standards).
\end{abstract}

Tilahun Weldie Hindeya *

\section{Key words}

Unilateral Trade Sanctions, Human rights, Repressive Governments, The

World Trade Organization, Extraterritorial Application

DOI http://dx.doi.org/10.4314/mlr.v7iL5

\section{Introduction}

Some Western countries have been utilizing unilateral trade sanctions as a means to combat human rights abuses in target countries. ${ }^{*} 1$ However, the use of

* LL.B (Bahir Dar University), LL.M (University of Pretoria and American University), Assistant Professor at Bahir Dar University School of Law. I am grateful to Hailegabriel Gedecho Feyissa and the anonymous reviewers for their insightful and valuable comments on earlier drafts of this article. All errors remain mine. The author can be reached at: tilahunw99@yahoo.com.

1 The US, Canada, and the European Union have all used different forms of trade sanctions against some governments that have allegedly been in gross violations of human rights. The US has imposed Sanctions against Burma, Cuba, and Zimbabwe. 
trade sanctions in general and unilateral trade sanctions in particular has become increasingly controversial. ${ }^{2}$ The dispute over unilateral trade sanctions does not, however, relate to the purpose intended to be achieved, i.e. the objective of promoting human rights, but rather to the question of whether these sanctions are the most effective weapons to achieve the goals. ${ }^{3}$ while some have regarded unilateral trade sanctions as an alternative way of defending human rights in target countries, there are concerns that such measures do not bring about the desired result but might rather inflict undesirable consequences on the general population. ${ }^{4}$ Furthermore, the efficacy of trade sanctions as a tool to promote human rights has evoked the debate over the relationship between trade measures and human rights. ${ }^{5}$

Targeted countries and countries that take such measures are mainly members of the wTO, and this has evoked the question of the legality of trade sanctions under the wTO. Apart from the controversy on the effectiveness of

Canada has also imposed sanctions against Burma and zimbabwe. Moreover, EU has also imposed unilateral trade sanctions against Burma, and zimbabwe. See generally Margaret Doxey (2009), "Reflections on the Sanctions Decade and Beyond", 64 International Journal at 539. For further explanation on some of the sanctions, see the last section of this article.

2 Trade sanctions can generally be divided into unilateral and multilateral sanctions. Multilateral sanctions are imposed by all countries in a given sanctions phenomenon and such sanctions are supported by the international community. On the other hand, unilateral sanctions are imposed by a country acting on its own /acting alone and may not have international support. See Thihan Myo Nyun (2008), "Feeling Good or Doing Good: Inefficacy of the US Unilateral Sanctions against the Military Government of Burma/Myanmar', 7 Washington University Global Studies Law Review 455 at 465 .

3 Id., at 457.

4 Holly Cullen (1999), "The Limits of International Trade Mechanisms in Enforcing Human Rights: The Case of Child Labour", The International Journal of Children's Rights, Vol.7 at 1.

5 Trade measures related to human rights can be "inwardly directed" or "outwardly directed." Inwardly directed trade measures are targeted towards ensuring that human rights are not violated within ones own territory. For instance, prohibition of importation of meat products for a certain period on grounds that the meat products imported from a given country can bring about health related problems (issues of human right to health) is an "inwardly directed" measure. On the other hand, outwardly directed trade measures, or commonly known as sanctions are targeted towards ensuring promotion of human rights in other countries. If the US takes trade measures against Syria aimed at promoting human rights in the country, the measure becomes "outwardly directed". The main focus of this article is on the latter measure. For further explanation on types of human rights related trade measures, see Jenny Schultz and Rachell Ball (2007), "Trade as a Weapon? The WTO and Human RightsBased Trade Measures”, Deakin Law Review, Vol. 12, No.1, at 43-44. 
such measures in inducing respect for human rights, the legality of the measures under the World Trade Organization (WTO) rules is questionable. The discussion in this article mainly focuses on WTO rules governing trade in goods. it is argued that unilateral trade sanctions against member countries on grounds of human rights violations are neither permitted under WTO rules nor effective mechanisms to ensure respect for human rights.

The first section of the article discusses the relationship between trade and human rights. This section provides some historical background to the relationship between trade and human rights in the context of the WTO. The second and third sections deal with the extent to which the WTO rules permit countries to take trade measures against other countries that do not comply with basic human rights standards. The last section discusses the ineffectiveness of unilateral trade sanctions to ensure that human rights are respected in other countries. it explores some of the trade sanctions that have been taken by western countries and assesses whether such measures have been effective in achieving the intended goals.

\section{Historical Background on the Relationship between Trade and Human Rights}

international trade law and international human rights have developed independently. ${ }^{6}$ The early international trade agreements did not accommodate issues that specifically deal with human rights. The human rights-trade link was almost absent in the early negotiations of the General Agreement on Tariffs and Trade (the GATT 1947). The only instance that can be taken as probably linking trade with human rights was the negotiations on labour issues during the early GATT period. ${ }^{7}$ Even so, it was not clear whether the negotiations on labour issues in the early GATT period were undertaken out of concern for human rights or purely targeted towards economic gains. ${ }^{8}$

6 Thomas Cottier (March 2002), "Trade and Human Rights: a relationship to Discover", 5 Journal of International Economic Law 111 at 112.

7 Labour issues are considered as human rights issues. Hence, the negotiations on issues related to labour may give us some clue on how issues of the human rights-trade link have been viewed by member countries in the history of the GATT 1947 and subsequently the GATT 1994.

8 Concern for labour issues may be viewed from different perspectives. some argue that labour standards should be protected out of concern to avoid child labour, forced labour, prison labour, etc. so that no person should be subject to exploitation. This concern that emanates from the idea that everyone's human rights should respected and protected. On the other hand, some argue that labour standards should be uniform out of fear that lower labour standards would enable some countries to produce products with lower cost. The price of such products may be lower as compared with the price of products that are manufactured in countries that have higher labour 
The International Trade Organization (ITO) Treaty was the first instrument that addressed labour issues in the context of a multilateral trade agreement. ${ }^{9}$ ITO never came into force. Instead, the GATT 1947 served as a transitional agreement until the WTO was established in 1994. However, Article VII of the ITO Charter still gives us some clue on whether the drafters had human rights issues in mind or were simply concerned with economic implications of labour. Article VII of the Charter provides:

The Members recognize that measures relating to employment must take fully into account the rights of workers under intergovernmental declarations, conventions and agreements. They recognize that all countries have a common interest in the achievement and maintenance of labour standards related to productivity, and thus in the improvement of wages and working conditions as productivity may permit. The Members recognize that unfair labour conditions, particularly in production for export, create difficulties in international trade, and, accordingly, each Member shall take whatever action may be appropriate and feasible to eliminate such conditions within its territory. ${ }^{10}$

As can be seen from the above provision, the drafters seem to have had some concern for the rights of workers and labour conditions in general. However, their main concern appears to be on labour conditions that have impact on the competitiveness of products in the international market. The last sentence of the provision, allows members to take measures that would eliminate conditions of unfair labour if it creates difficulties in international trade. Hence, the primary concern the ITO Charter was how to create fair competition in international market rather than ensuring human rights were respected.

The ITO Charter (Havana Charter) was not ratified and eventually abandoned after 1950. ${ }^{11}$ With the failure to adopt the Havana Charter, the parties to the agreement resorted to negotiations on tariff concessions. This has given rise to GATT 1947 which did not contain a provision comparable to Article VII of the Havana Charter.

standards. Hence, the products manufactured in countries with higher labour standards will be at a disadvantage in terms of market access. Therefore, the countries that have higher labour standards favour uniform application of such standards, not out of concern for respecting and protecting human rights but for fear that their products would otherwise be at a disadvantage.

9 Elissa Alben (2001), "GATT and the Fair Wage: A Historical Perspective on the Labor-Trade Link”, 101 Columbia Law Review 1410 at 1430.

${ }^{10}$ Ibid.

11 Ibid. 
The issue of labour re-emerged under the GATT 1947 in 1952 when Japan applied for accession to the GATT 1947. ${ }^{12}$ The labour standards of Japan were criticized mainly by the US and Britain who were reluctant to endorse Japan's application to accede to the WTO. Their concern was based on unfair competition from Japanese products that would be manufactured by "unfair labour standards". ${ }^{13}$ Hence, the negotiators of GATT 1947 did not want to link trade with labour rights in particular and human rights in general.

in the period after the early negotiations until the establishment of the WTo (1994), the human rights-trade link was not a major agenda in the international trade arena since countries have diverging views on the issues, and majority of the countries vehemently rejected the incorporation of labour standards into the GATT $1947 .{ }^{14}$

The creation of the WTO in 1994 generated a reaction across a wide range of groups in many countries on the ground that it has not taken or should take into account non-trade issues such as human rights and environment. ${ }^{15}$ More specifically, the introduction of General Agreement on Tariffs and Trade (GATT 1994) gave rise to a debate into the relationship between trade and human rights. ${ }^{16}$

The link between international trade and human rights has become an issue of increasing interest for developing and developed countries, non-governmental organisations (NGos) and international organizations. interestingly, scholarly opinion is divided on the issue whether WTo Agreements imply any clear linkage between international trade and human rights. While some argue that trade sanctions can lawfully be imposed on human rights grounds, others challenge such arguments. The following section briefly forwards the legal framework under the WTo and the major points invoked in support of and against such arguments.

12 Id at 1432.

13 Britain's products were facing a potential flood of imports of products made with cheaper Japanese labor. The US also had concern with labor standards of Japan on ground of 'unfair' trade competition. The negotiators also continuously referred to the possibility that Japan could use lower labor standards as affecting competition of foreign markets. See Alben, supra note 9, at 1433-1444.

14 Salman Bal (2001), "International Free Trade Agreements and Human Rights: Reinterpreting Article XX of GATT”, 10 Minnesota Journal of Global Trade 62 at 66.

15 See generally Sara Dillon (2002), “A Farewell to Linkage: International Trade law and Global sustainability Indicators", 55 Rutgers Law Review 87.

16 Carlos Manual Vazquez (2003), "Trade sanctions and Human Rights- Past, Present, and Future", 6 Journal of International Economic Law 797 at 801. 


\section{Trade Measures and Human Rights under the GATT 1994}

\subsection{Provisions Relevant to Human Rights Related Trade Measures under the GATT: Legal Framework}

The most relevant WTO rules regarding trade measures related to human rights are Articles I, III, XI, XX and XXI of GATT 1994. Articles I and III lay down non-discrimination rules. Article $\mathrm{Xi}$ of the GATT governs the prohibition of quantitative restriction (both import and export) subject to few exceptions. Article I of the GATT provides the Most-Favoured-Nation treatment (MFN) principle. It stipulates that “....any advantage, favour, privilege or immunity granted by any contracting party to any product originating in or destined for any other country shall be accorded immediately and unconditionally to the like product originating in or destined for the territories of all other contracting parties". ${ }^{17}$ According to this principle, products of a country should be treated equally with like products of other WTO members. ${ }^{18}$

Article III deals with national treatment (NT) principle. It provides that any internal charges, laws, regulations or requirement related to products of a contracting party should not be applied to imported or domestic products so as to afford protection to domestic production. ${ }^{19}$ Articles I and III of the GATT generally prohibit discrimination of products from a member country either as compared with products of third contracting parties or as compared with products of the country taking the measure. Hence, if any human rights related trade measure is inconsistent with Article I and III, it must be justified under the exceptions. Otherwise, it would be illegal under the GATT.

17 General Agreement on Tariffs and Trade, Marrakesh Agreement Establishing the World Trade Organization (April, 1994); results of the Uruguay Round of Multilateral Negotiations, Article I(1). ( Hereinafter the GATT )

8 Assume that Country $\mathrm{X}$ - a developed country takes trade measures against Country $\mathrm{Y}$ (by way of imposing higher tariffs on some products that originate from Country $\mathrm{Y}$ while it imposes lower tariff to other contracting parties) in order to discourage the flow of trade from Country $\mathrm{Y}$ in response to human rights violations in Country $\mathrm{Y}$. This measure would violate the MFN principle. The question then becomes whether Country X can justify its measure by other WTO rules, particularly Article XX of GATT.

19 GATT 1994, Article III (I). A country that discriminates between its products and products from a contracting party on the basis that the products from the member contracting party have been produced in violations of human rights or on grounds of gross human rights violations in the country in general would violate Article III of the GATT. For such measure to be legal under the WTO, it should be justified by another rule of the WTO that may be an exception to Article III of the GATT 1994. 
Article XI of the GATT which deals with prohibition of quantitative restrictions provides:

No prohibitions or restrictions other than duties, taxes or other charges, whether made effective through quotas, import or export licences or other measures, shall be instituted or maintained by any contracting party on the importation of any product of the territory of any other contracting party or on the exportation or sale for export of any product destined for the territory of any other contracting party. ${ }^{20}$

Hence, contracting parties are prohibited from banning products totally from entering into their own territory or imposing quota restrictions on products that enter to their territory. Restrictions on the exportation of products into the territory of other contracting parties are also prohibited. There are exceptions provided to this prohibition. However, recourse to trade measures for promotion of human rights in other countries is not included under the list of exceptions. ${ }^{21}$

in light of the above discussion, the imposition of trade restrictions against contracting parties on the basis of human rights violations outside the territory of a country violates the major principles mentioned above unless the measure is justified by Articles XX and XXI which embody exceptions of the GATT. If trade measures related to human rights fall within the scope of Article XX and XXI exceptions, such measures would not be illegal under the WTO rules even when they might be inconsistent with the basic principles of the GATT. However, whether such measures fall within the Article XX or XXI exceptions remains controversial. Let us first see the content of Article XX before further examining whether such measures can be justified. Article XX of GATT in part reads:

\section{General Exceptions}

subject to the requirement that such measures are not applied in a manner which would constitute a means of arbitrary or unjustifiable discrimination between countries where the same conditions prevail, or a disguised restriction on international trade, nothing in this Agreement shall be construed to prevent the adoption or enforcement by any contracting party of measures:

20 GATT 1994, Article XI(1).

21 The Exceptions provided under Article XI(2) include: Export prohibitions or restrictions temporarily applied to prevent or relieve critical shortages of foodstuffs or other products essential to the exporting contracting party; Import and export prohibitions or restrictions necessary to the application of standards or regulations for the classification, grading or marketing of commodities in international trade; Import restrictions on any agricultural or fisheries product, imported in any form, necessary to the enforcement of governmental measures and other exceptions include restrictions to safeguard the balance of payments (Article XII) and safeguards to protect domestic industry (Article XIX) of the GATT. 
(a) necessary to protect public morals;

(b) necessary to protect human, animal or plant life or health;

(e) relating to the products of prison labour;

(g) relating to the conservation of exhaustible natural resources if such measures are made effective in conjunction with restrictions on domestic production or consumption;

Two requirements should be fulfilled to justify a measure under Article XX. Firstly, the measure must fall under the list of exceptions provided under Article XX (a-j). Secondly, the measure must meet the conditions stipulated in the introductory phrase of Article XX (commonly known as the chapeau). As can be seen from Article XX reproduced above, human rights values are not expressly stated under the list of exceptions. The question thus becomes whether human rights violations can, by means of interpretation, be within the scope of Article XX list of exceptions. The following section discusses the arguments for and against.

\subsection{Arguments for Trade-human Rights Link on the basis of Article XX Interpretation}

Some argue that Article XX of the GATT 1994 can be a legal backdoor for the protection of human rights. For instance, Salman Bal argues that there is a direct and appropriate relationship between international trade and the protection of human rights. ${ }^{22}$ According to Bal, a look at the provisions of GATT Article XX (a), (b), (d) and (e) reveals that these WTO rules can be used to protect human rights. Article $\mathrm{XX}$ is an exception to the provisions of GATT. Members can derogate from other obligations provided that they satisfy the requirement of the chapeau and there is a necessity to protect public morals (Article XX (a)), to protect human, animal or plant life or health (Article XX (b)), to secure compliance with laws or regulations which are not inconsistent with the provision of this agreement (Article XX (d)) and relating to the products of prison labor (Article XX (e)). According to Bal, although the provisions do not explicitly mention human rights, the list of exceptions under Articles XX(a), (b), (d) and (e) are indicative of the fact that non-trade issue can be given priority over free trade. ${ }^{23} \mathrm{Bal}$ states that the wording of the provision such as public morals, human life, and products of prison labour can be interpreted to accommodate human right issues.

22 Bal, supra note 14 , at 63.

23 See generally Bal, supra note 14. 
Powell also argues that there is a room to implement human rights in the WTO. He argues that the aim of the WTO is not limited to promoting free trade. It is also concerned with non-trade issues. He states that although the WTO mainly aims to encourage economic growth through free trade, it also gives space to non-trade issues because "the preamble to the Marrakesh Agreement establishing the WTO does not make free trade an end in itself, but a means to fulfil basic human rights such as the improvement of global standards of living, promotion of sustainable development, and preservation of the environment". 24 Powell advances the view that the terms such as 'global standard of living' and 'promotion of sustainable development' can be interpreted to accommodate human rights.

Powell further argues that Article XX can be a back door to defend the implementation of human rights through the WTO. This provision enumerates different public welfare policies the WTO members may take even in a situation where the measures may restrict trade. ${ }^{25}$ Therefore, members are given the right to take some actions which could derogate from the rules of the WTO in order to protect human life or health. The concern for human health and life indeed verifies the concern for human rights. Moreover, the fact that the WTO Agreements on sanitary and Phytosanitary and on Technical Barriers to Trade allow countries to take trade measures needed to protect human life or health is another evidence that WTO does not have free trade as an end in itself. ${ }^{26}$ Powell also makes reference to some of the flexibilities under the Trade Related Aspects of Intellectual Property Rights (TRIPS) Agreement to support his view regarding the place of human rights in the WTO system. Hence, the provisions of these different WTO Agreements clearly involve human rights. ${ }^{27}$

Likewise, Ernst-Ulrich Petersmann contends that human rights can be a legally relevant context for the interpretation of WTO rules. According to Petersmann, the WTO appellate body has consistently decided that international customary law and Article 3.2 require an interpretation of WTO rules in good faith, in accordance with the ordinary meaning to be given to the terms of the treaty in their context and in the light of its object and purpose. He thus contends

24 Stephen J. Powell (2004), "The Place of Human Rights Law in World Trade Organization Rules", 16 Florida Journal of International Law 219 at 221.

${ }^{25} \mathrm{Id}$, at 222.

26 See generally Agreement on the Application of Sanitary and Phytosanitary Measures, Marrakesh Agreement Establishing the World Trade Organization (April, 1994); results of the Uruguay Round of Multilateral Negotiations. See also Agreement on Technical Barriers to Trade. It is important to note that there are procedures to be followed before taking action on the basis of the above agreements.

27 Powell, supra note 24, at 223. 
that this means of interpretation leads to the conclusion that some WTO provisions can be interpreted to defend human rights. ${ }^{28}$

\subsection{Arguments against Human Rights Related Trade Sanctions Under the GATT}

Other scholars argue that the wTO rules do not authorize countries to take outwardly directed trade measures (to which the author of this article subscribes) on grounds of human rights violations.

The list of exceptions under Article XX which may be relevant to human rights related trade measures are Article XX (a), (b) and (e). Article XX (a) embodies the notion of public morals exception. There is no definition provided as to what constitute public morals. The question of what violates public morals seems to be determined by each country as there is no universal standard of what constitute public morals. what is moral in one country can be immoral in another country. This exception has also hardly been applied or mentioned in reports of the Dispute settlement Body (DSB). The notion of public morals has only been discussed once by the Dispute Settlement Body in US - Gambling services case $^{29}$ Even then, it was not an interpretation of public morals under Article XX (a) of the GATT but rather was an interpretation of the public morals exception under Article XIV of General Agreement on Trade in Services (GATS). The panel in this case noted that public morals and public orders "can vary in time and space, depending upon a range of factors, including prevailing

28 Ernst-Ulrich Petersmann (2004), “The 'Human Rights Approach' Advocated by the UN High Commissioner for Human Rights and by the International Labour Organization: Is It Relevant for WTO Law and Policy?", 7 Journal of International Economic Law 605 at 608. Incidentally, Petersmann also calls for institutional change of WTO so that it can incorporate human rights issues. He argues that WTO (like EC), can and should become an advocate not only for economic freedom but also promotion of human rights. See Ernst-Ulrich Petersmann (2000), "The WTO Constitution and Human Rights", Journal of International Economic Law, Vol.3, Iss. 1 at 19. According to Petersmann, human rights should be recognized in laws such as the WTO that facilitate global integration so as to require governments to protect and promote human right in all policies across national frontiers. He argues that the WTO should take lessons from the regional experiences in Europe and should stop focusing on one-sided trade liberalization. He rather contends that global integration law in the WTO must advance not only economic efficiency but also human rights protection and promotion. See Ernst-Ulrich Petersmann (2002), "Time For a United Nations 'Global Compact' for Integrating Human Rights into the Law of Worldwide Organizations: Lessons from European Integration", 13 European Journal of International Law 621 at 622.

29 United States - Measures Affecting the Cross-Border Supply of Gambling and Betting Services, WT/DS285/R (Hereinafter US-Gambling case). 
social, cultural, ethical and religious values". It also stated that in applying these concepts "[m] embers should be given some scope to define and apply for themselves the concepts of 'public morals' and 'public order' in their respective territories, according to their own systems and scales of values". 30

Given the fact that the definition and application of public morals will differ according to the circumstances of each country, it would be difficult to equate the concept of public morals to human rights that have universal recognition. Hence, the concept of public morals under Article XX (a) hardly refers to the human rights discourse.

Proponents of the argument that human rights can be taken into account under international trade rules mainly invoke Article XX(b) of the GATT. one of their main arguments is that the phrase "necessary to protect human health or life' can accommodate human right issues. However, it is important to note that 'necessary to protect human health or life' does not necessarily address issues of human rights. This is not to suggest that all issues related to public health and life are out of the realm of human rights because there are indeed human health and life issues that may be regarded as human rights.

In line with the above arguments, Robert Howse contends that relying on Article XX of GATT to show that human rights are accommodated under the WTO is flawed. ${ }^{31}$ According to Howse, the existing exceptions in Article XX of the GATT refer to a wide range of policy objectives that may or may not be regarded directly referring to human rights. ${ }^{32} \mathrm{He}$ further posits that the WTO Appellate Body would find it very difficult to appreciate the relevance of human rights to a WTO's member's defense of its policies based on Article XX of GATT. Accordingly, he argues the different rulings of the Dispute Settlement Body (DSB) do not imply that Article XX of the GATT can be relevant to human rights. ${ }^{33}$

${ }^{30}$ US-Gambling case, paragraphs 6.459-461.

${ }^{31}$ See generally Robert Howse (2002), "Human Rights in the WTO: Whose Rights, What Humanity? Comment on Petersmann" European Journal of International Law, Vol. 13 No.3. Howse has written in response to Petersmann's proposition that the WTO should be transformed into a 'constitutionalized organization' modelled on the European Community so that the WTO can effectively deal with matters of not only $32 \mathrm{tr}$ trade but also human rights.

33 Howse notes that "[t]he extent to which environmental concerns are appropriately translated into the notion of 'environmental rights' is quite controversial, and in the presence of this controversy, and given the institutional context of the WTO, the Appellate Body might well be inclined to take a cautious or conservative view." $\mathrm{He}$ also argued that in the Shrimp/Turtle case the "Appellate Body did not link the notion of conservation of exhaustible natural resources to human rights values" See Howse, supra note 31 at 656 . 
Alston also doubts the appropriateness of enforcing human rights through the WTO. He contends that the power and objectives of the WTO are narrowly focused around the goal of expanding the production of trade in goods and services. Alston observes that the WTO law, as it stands now does not have mandate over issues of human rights. ${ }^{34}$

While it is fair to say that the list of exceptions under Article XX of the GATT (such as public health) refer to protection of the human right to health, its application is limited in the sense that derogation from the WTO rules can be made only to address public concerns within domestic jurisdiction. In other words, even when the above lists of exceptions are interpreted to refer to the human rights language, the trade restrictions to be applied by members should only be imposed to address policy objectives within one's own territory and not to address human rights concerns in the territory of other countries. This is because, as shall be explained under section 3, members cannot impose trade measures to promote social concerns outside their own territory (jurisdiction). Article XX does not warrant extraterritorial application.

Article XX(e) allows members to take trade measures relating to the products of prison labour. This provision is probably the only exception under Article XX where members may take trade measures to address problems outside their territory. This implies that members may take trade measures to address human rights concerns in general and labour standards in particular in other countries.

However, the historical context suggests otherwise. It suggests that "the object and purpose of this provision is not a humanitarian one, i.e. to prohibit prison labor in general, but to protect competition of national products produced with regular work force, which are of course more expensive than products produced with prison labor." 35

Moreover, a close look at the drafting history of the provisions of the GATT does not support the assertion that human rights were part of the GATT. The principles of interpretation in international law as enshrined in the Vienna

34 Philip Alston (2002), "Resisting the Merger and Acquisition of Human Rights by Trade Law: A Reply to Petersmann", European Journal of International Law, Vol. 13, No. 4, at 30. Alston wrote the article in reply to Petersmann's proposal that human rights can effectively be enforced through the WTO. He further argues that enforcement of human rights through the WTO is not appropriate. He also raises many defects of the WTO that limits its competence to deal with human right issues. $\mathrm{He}$ argues that the interests of many stakeholders is not represented and "its institutional structure, its processes and the outcomes it sanctions are far from what would be required of a body to which significant human rights authority could be entrusted." See Alston, at 836.

35 Gudrun Zagel (2004), "The WTO and Trade-Related Human Rights Measures: Trade Sanctions Vs. Trade Incentives", 9 Austrian Review of International and European Law 119 at 135. 
Convention on the Law of Treaties guide the interpretation of WTO agreements. ${ }^{36}$ Article 32 of the Vienna Convention provides for reliance upon supplementary means of interpretation which includes both the preparatory work of the treaty and the circumstances surrounding the treaty's conclusion. ${ }^{37}$ Looking into the negotiating history is one of the means of interpretation that falls within the ambit of Article 32 of the Vienna Convention. ${ }^{38}$

Hence, the interpretation of Article XX in light of its negotiating history indicates that the negotiating parties never intended for the enforcement of human rights to constitute an exception under Article XX. ${ }^{39}$ Even Article 7 of the Havana Charter of ITO, the provision often cited by some as a historical legal basis for trade measures against human rights violations ${ }^{40}$ does not allow countries to take trade measures on grounds of human rights violations in the territory of another country. It rather focuses on the link between labour and productivity. Article 7 of the Havana Charter provides:

The Members recognize that measures relating to employment must take fully into account the rights of workers under inter-governmental declarations, conventions and agreements. They recognize that all countries have a common interest in the achievement and maintenance of fair labour standards related to productivity, and thus in the improvement of wages and working conditions as productivity may permit. The Members recognize that unfair labour conditions, particularly in production for export, create difficulties in international trade, and, accordingly, each Member shall take whatever action may be appropriate and feasible to eliminate such conditions within its territory. 41

Eres contends that if Article 7 was so concerned with human rights, it would not have focused on productivity by using the phrase 'labor standards related to productivity.' He further argues that to condition maintenance of labor standards on productivity is inconsistent with the rights based approach. ${ }^{42}$ Therefore, it would be wrong to conclude that it was linked to human rights. The provision also reflects the preoccupation of the negotiating parties with fair trade by addressing the fact that low labour standards provide some members with an unfair competitive advantage. Conditioning respect for labor standards on competitive advantage is consistent with the drafters' intent to prevent unfair

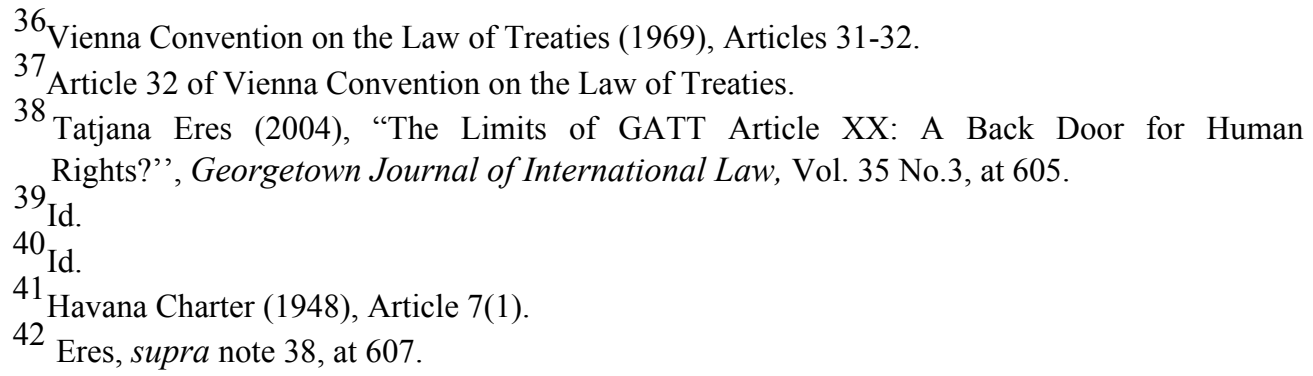


trade, not to enforce human rights. ${ }^{43}$ In sum, the context of Article 7 shows the intention of the drafters to prevent unfair competition specifically through the role of labor as a cost of production, and not for enforcement of human rights. Therefore, the argument that Article XX of GATT warrants the imposition of unilateral trade sanctions against other members on grounds of gross violations of human rights would be hardly convincing.

However, it is important to note that members may take trade measures based on the security exceptions enshrined in Article XXi. wTO members may deviate from their obligations under the GATT provided that they do so under some conditions and to protect their essential security interests. Members can take any measure they deem appropriate in relation with the trafficking of arms or trafficking in any other goods which are intended for the purpose of supplying a military establishment. ${ }^{44}$ As can be seen from this provision, countries may unilaterally put restrictions on the flow of goods only when such goods are to be used for a military establishment.

Moreover, members may take trade measures that are necessary for the maintenance of peace and security in pursuance of their obligations under the United Nations' Charter (UN Charter). ${ }^{45}$ Trade measures can be authorized as economic sanctions by the UN Security Council within the system of collective security under Chapter VII of the UN Charter. ${ }^{46}$ Hence, the Security Council can authorize multilateral trade sanctions in order to maintain or restore international peace and security. Article XXI(c) of the GATT allows WTO members to impose trade sanctions only when the Security Council calls upon countries for multilateral action which may include trade embargo. However, unilateral trade sanctions are neither covered under Article XXI exception of the GATT nor under the UN Charter.

\section{Extraterritorial Application, Process-Production Methods (PPMs) under GATT 1994 and Human Rights}

In dealing with Article XX of GATT, we also need to see the extraterritorial application of this provision. Taking trade measures on the basis of human rights violations that happen in another country shall be based on WTO rules. However, Article XX does not allow countries to take trade measures for acts

43 Id.

${ }^{44}$ GATT 1994, Article XXI (b) (ii). A member may also take any action necessary for the protection of its essential interests relating to fissionable materials from which they are derived (Article XXI (b) (i)).

45 GATT 1994, Article XXI (c).

${ }^{46} \mathrm{UN}$ Charter, Article 39 and Article 41. It has to be noted that all members of the UN have the obligation to abide by the decision of the Security Council (Article 25 of the UN Charter). 
done in another country. In other words, the provision does not have extraterritorial application.

The WTO Dispute Settlement Body (DSB) has not yet conclusively decided on the issue of extraterritorial application of Article XX of GATT in relation to human rights. However, this issue has been incidentally examined in the context of environmental concerns which could indicate the position of the DSB. In a case involving Mexico and the United States (Tuna-Dolphin case), Mexico challenged the use of a ban on imports by the United States and the Panel ruling on the issue of extraterritoriality stated that:

Nothing in Article XX entitled any contracting party to impose measures in the implementation of which the jurisdiction of one contracting party would be subordinated to the legislation of another contracting party. It could be deduced from the letter and spirit of Article XX that it was confined to measures contracting parties could adopt or apply within or from their own territory. To accept that one contracting party might impose trade restrictions to conserve the resources of another contracting party would have the consequence of introducing the concept of extraterritoriality into the GATT, which would be extremely dangerous for all contracting parties. ${ }^{47}$

The ruling shows that using trade measures for events that happen outside the jurisdiction of a country is dangerous for the promotion of international trade and it is not also supported by Article XX of GATT. Therefore, taking trade sanctions on grounds of human rights violations in another country adversely affects the promotion of international trade. Moreover, as confirmed by the Panel, such measure is not warranted under the GATT.

There is a decision by the DSB of the WTO regarding environmental issues which might be in apparent contradiction with the above decision. It appears that in Shrimp-Turtle case some extraterritorial measures fall within Article XX exceptions as both the Panel and the Appellate Body accepted that the measures taken by the US to protect sea turtles which were outside US territorial waters was acceptable. ${ }^{48}$ This may be viewed as the extraterritorial application of Article XX of GATT. Nevertheless, the Appellate Body explicitly stated that it was not deciding the issue of jurisdiction on the basis of WTO law. The Appellate Body stated that "we do not pass upon the question of whether there is an implied jurisdictional limitation in Article XX (g) and if so, the nature and extent of the limitation" and it noted that "in the specific circumstances of the case before us there is a sufficient nexus between the migratory and endangered marine populations involved and the United States for the purpose of Article XX

47 GATT Dispute Panel Report on United States: Restrictions on Imports of Tuna, Aug. 16, 1991, GATT B.I.S.D. (39th Supp.), (1993), para 170.

48 Appellate Body Report, United States-Import Prohibition of Certain Shrimp and Shrimp Products, (WT/DS58/AB/R (12 October 1998) (Hereinafter US-Shrimp case). 
(g)". ${ }^{49}$ Thus, the Appellate Body found that the extraterritorial measure by the US was acceptable not because it was convinced that the provision permits taking measures for acts outside the jurisdiction of a country but because the act outside the jurisdiction of the US involved the interest of the US in its marine population.

Hence, extraterritorial application of Article XX of the GATT can hardly be valid for human right violations that happen outside one's own jurisdiction. Therefore, imposing trade sanctions against another member on grounds of human rights violations that happen outside the territory of a given country appears to lack a legal back up under the GATT.

The trade measures against human right violations also raise the issue of distinction in process-production methods (PPMs) as there is a question whether GATT measures apply only to the final product or to the methods of production as well. Human rights issues can arise in connection with violations that may occur in the process of production, in cases such as child labour and forced labour.

The WTO has not decided on the validity of human rights PPMs but its decision on environment PPMs may give some clue in this regard. ${ }^{50}$ The TunaDolphin dispute involved a US restriction on the importation of tuna that had been caught in a manner that endangered dolphins. ${ }^{51}$ The US tried to justify the measure as necessary to protect animal health in Mexico. Mexico argued that the exception applied only to measures designed to protect the health of dolphins within the United States. The GATT Dispute Settlement Panel agreed with Mexico's argument declaring that this was a breach of GATT norms not to discriminate between like products on the basis of how the products had been produced. ${ }^{52}$ The Panel stated:

the standard of Article iii - namely that imported products be accorded no less favorable treatment than domestic products - required a comparison between products of the exporting and importing countries, and not a comparison between production regulations ... that had no effect on the product as such. Therefore, the United States could not embargo imports of tuna products from Mexico simply because Mexico's regulations affecting the production of tuna did not satisfy United States regulations. ${ }^{53}$

49 US-Shrimp case, para 133.

${ }^{0}$ Vazquez, supra note 16 at 812.

1 Panel Report, United States-Restrictions on Imports of Tuna, 3 September 1991, DS21/R, BISD 395/155 (Hereinafter US-Tuna case).

52 Ibid.

53 US-Tuna case, para 201. 
This ruling suggests that if the qualities of products meet the standards set by countries, then members should not impose different treatments against products based on the process through which they have been produced. Furthermore, this ruling seems to have some support by the panel in US-Shrimp case. In this case the panel ruled that to adopt trade restrictive measures, conditioning access to its market for a given product upon the adoption of certain policies by the exporting country would be extremely dangerous for functioning of the WTo multilateral trading system. ${ }^{54}$

on the contrary, some scholars argue that PPMs are allowed as per Article $\mathrm{XX}$ of GATT. The prison labour exception under Article $\mathrm{XX}(\mathrm{e})$ is mainly invoked to support such argument. For instance, Bal rejects the argument that products should not be banned from being imported or restricted quantitatively on the basis of the process in which they have been produced. Bal contends that Article XX (e) which deals with prison labour does not have anything to do with the final product. it deals with the products manufactured using prison labour in another country. Hence, it is related to the process of how the product is made. Eventually, such provision which permits trade action on the basis of how a product is produced can be used in dealing with issues of human rights by analogy. 55

54 US-Shrimp turtle case, para 7.45. The Panel in this case noted that "In our view, if an interpretation of the chapeau of Article XX were to be followed which would allow a Member to adopt measures conditioning access to its market for a given product upon the adoption by the exporting Members of certain policies, including conservation policies, GATT 1994 and the WTO Agreement could no longer serve as a multilateral framework for trade among Members as security and predictability of trade relations under those agreements would be threatened. This follows because, if one WTO Member were allowed to adopt such measures, then other Members would also have the right to adopt similar measures on the same subject but with differing, or even conflicting, requirements. if that happened, it would be impossible for exporting Members to comply at the same time with multiple conflicting policy requirements. Indeed, as each of these requirements would necessitate the adoption of a policy applicable not only to export production (such as specific standards applicable only to goods exported to the country requiring them) but also to domestic production, it would be impossible for a country to adopt one of those policies without running the risk of breaching other Members' conflicting policy requirements for the same product and being refused access to these other markets. We note that, in the present case, there would not even be the possibility of adapting one's export production to the respective requirements of the different Members. Market access for goods could become subject to an increasing number of conflicting policy requirements for the same product and this would rapidly lead to the end of the WTO multilateral trading system."

${ }^{55} \mathrm{Bal}$, supra note 14 , at 86. 
However, as explained earlier, the historical context of this provision suggests that the purpose of this provision is not to address human rights concerns but rather protection of products manufactured through normal labour force against competition of products manufactured through unfair labour.

\section{Ineffectiveness of Trade Sanctions to Enforce Human Rights Protection}

Countries take trade sanctions to make sure that allegedly repressive governments comply with human rights standards. However, many trade sanctions intended to assure respect for human rights have failed to bring about the compliance of the violators of human rights. Rather, they may be counter productive resulting in further violations of human rights.

Trade or economic sanctions are controversial measures. Proponents of trade sanctions assert that sanctions can bring about the necessary restraint on authoritarian governments on their violation of human rights. ${ }^{56}$ They argue that these sanctions oblige a repressive regime to comply with the conditions set by the country imposing the sanction. ${ }^{57}$

On the other hand, free trade economists and many developing countries generally oppose the linkage between human rights and trade sanctions. ${ }^{58}$ They argue that such linkage works against the promotion of welfare. They also contend that it is to the disadvantage of the economy of developing countries as it limits their export to the fullest extent possible. what is more, linking trade with human rights would deprive the developing countries of their comparative advantage in the use of cheap labour. ${ }^{59}$ Developing countries may not effectively use their cheap labour for the fear that trade sanctions might be imposed by the developed world on grounds of violations of labour standards. Hence, the linkage opens a door for abuse. This leads to the use of trade measures simply for a protectionist purpose. ${ }^{60}$

Moreover, there is evidence that trade or economic sanctions are not effective to bring about the desired result. Hence, some argue that trade sanctions particularly unilateral sanctions should not be employed, and suggest that countries should rather resort to constructive engagement. The principle behind this argument is that economic transactions will create capital flows and

56 See Audie Klotz (1998), "Making Sanctions Work: Comparative Lessons", in Neta Crawford \& Audie Klotz (eds.,), How Sanctions Work: Lessons From South Africa, 57 Ibid.

${ }^{58} \mathrm{Bal}$, supra note 14 , at 64 .

59 ibid.

60 ibid. 
these capital flows which create new jobs and increase production will ultimately lead to political and social changes. ${ }^{61}$ It is also argued that constructive engagement expands the middle class. ${ }^{62}$

it is conceivable that the expansion of the middle class will improve the social and economic rights of citizens. Advocates of economic engagement also contend that "increased economic and social wealth for the citizens of the target country and its increased presence in the world community, will generally lead to faster improvement in the political and social situation than with sanctions". ${ }^{63}$ It is argued that a "country and its political and social climate" can benefit from "the influence of wealth, security and foreign values" and that "a restrictive or repressive state", may 'evolve' "into a more open, protective state cognizant of, and responsive to, its citizens' appeals for change. This evolution would be aided by private and public appeals to the government for change". 64

China can be cited as an example where some improvement has been observed after the country opened its door for trade and foreign investment. it is also argued that the economic transaction coupled with the exposure to the international world will prompt the citizens mainly the middle class to demand more freedom and respect for human rights. ${ }^{65}$ As more economic transaction develops "a middle class motivated by the taste of what economic and social freedoms have to offer-will develop with the intense desire to change the government and the increased power to do so". 66

one of the strongest arguments against trade sanctions is that the general public often is most hurt rather than the political elite. ${ }^{67}$ Those who control power will have different mechanisms in place to make sure that they get what they want. On the contrary, the general public who does not have many choices will suffer. Especially, sanctions will be counterproductive due to job losses and

${ }^{61}$ See Monthly Review, Constructive Engagement in Areas of Conflict, (2010) available at: $<$ http://www.sustainability.co.uk/monthly-review/April2000perspective-engagement.htm>, (Accessed on Sept. 2010).

${ }^{62}$ Mark A.Warner (1999), "Globalization and Human Rights: An Economic Model", 25 Brooklyn Journal of International Law 99 at 110.

${ }^{63}$ Mark B. Baker (Fall, 2002), "Flying Over the Judicial Hump: a Human Rights Drama Featuring Burma, the Commonwealth of Massachusetts, the WTO and the Federal ${ }^{64}$ Ibid Courts", 32 Law \& Policy in International Business 51 at 80.

65 ibid.

66 Ibid.

67 Adrienne S. Khorasanee, "Sacrificing Burma to Save Free Trade: The Burma Freedom Act and the World Trade Organization", 35 Loyal of Los Angeles Law Review 1295 at 1314. 
deepening poverty. ${ }^{68}$ This would in turn exacerbate the human rights situation in the state concerned.

One study on effectiveness of economic sanctions concludes from an analysis of more than hundred cases that they have worked only in about one third of the cases. ${ }^{69}$ Many trade sanctions have done little to hurt those in power and failed to ensure human rights are respected. ${ }^{70}$ This is on account of the fact that the targeted regimes are able to develop alternative means of circumventing the sanctions. There is evidence that even multilateral trade restrictive measures rarely stop human rights abuse because there is a high incentive for trading partners to disregard the sanction. ${ }^{71}$ For instance, states had a high incentive to violate multilateral trade sanctions against Iraq. ${ }^{72}$ There is evidence that France and Germany secretly traded with Iraq. ${ }^{73}$

A prime example where unilateral trade sanctions have failed to bring compliance with human rights standards is Burma (Myanmar). ${ }^{74}$ The people of Myanmar live under an authoritarian regime that is widely condemned for its repressive policies and serious human right abuses. ${ }^{75}$ Military regimes in one form or another have controlled Burma for over 40 years. ${ }^{76}$ After its independence in 1948 from Britain until 1962, Myanmar had a parliamentary democracy under the elected leadership of prime minister $\mathrm{U} \mathrm{Nu} .{ }^{77}$ It was in 1962 that General $\mathrm{Ne}$ Win came to power by overthrowing the elected civilian

68 Ibid.

69 GC Hufbauer et al., Economic Sanctions Reconsidered: History and Current Policy (1990, 2nd ed., Washington Dc.: Institute for International Economics) at 93.

70 Ernest H. Preeg (1999), Feeling Good or Doing Good with Sanctions: Unilateral Economic Sanctions and the US National Interest 11-87 (Washington DC.: Center for Strategies and International studies).

71 Jagdish Bhagwati (1998), "Trade Linkage and Human Rights", in Jagdish Bhagwati and Mathias Hirch (eds.) The Uruguay Round and Beyond: Essay in Honor Of Arthur Dunkel (Ann Arbor, Mich: Michigan University Press) at 243-44.

72 Ibid.

73 Adrew K. Fishman (1999), "Between Iraq and a Hard Place: The Use of Economic Sanctions and Threats to International peace and Security", 14 Emory International Law Review 687 at 687.

74 The official name of Burma is Myanmar. It is, however, commonly known by the name Burma.

75 M P Daley, Current Situation In Burma, Testimony before the Subcommittee on East Asia and the Pacific, House International Relations Committee, at a Hearing on Burma ( Washington, 2003)

Available at; <http:// www.state.gov/p/eap/rls/rm/2002/11264.htm> , (Accessed on February 2010)

76 Ibid.

77 Khorasanee, supra note 67. 
government. ${ }^{78}$ After 25 years military rule, in 1988, the people of Myanmar demonstrated against the regime. The military government suppressed those demonstrations killing hundreds of protestors, and subsequently imprisoning many in harsh and fatal conditions. ${ }^{79}$

in the 1990s the occasional public protest that was suppressed through arrest and imprisoning anyone who advocated for human rights and democracy. ${ }^{80}$ The military government's human rights record remains very poor with repression of political opposition, forced labour, ethnic persecution, and lack of religious freedom even after the year $2000 .{ }^{81}$

In response to the human right violations in Myanmar, trade and other types of measures have been taken by the US. In 1989 the United States suspended millions of dollars in aid and requested other countries to take similar measures. ${ }^{82}$ The United States also suspended Myanmar's preferred trading status in the same year on grounds of human right violations. ${ }^{83}$ In 1990 the United States adopted legislation which empowered the president to take economic sanctions as the president thinks appropriate provided that the Myanmar military government fails to take steps for democratization. ${ }^{84}$

In 1996 president Clinton signed into law the 1997 Foreign Operations Act which gave the president the discretion to prohibit individuals in the US from initiating investments in Myanmar. ${ }^{85}$ It was followed by an executive order implementing the provisions in the Foreign operations Appropriations Act which prohibited any new investment in Myanmar and expansion of trade commitments. ${ }^{86}$ Furthermore, in response to the report of 2002 and arrest of the

78 Michael Ewing-chow (2007), "First Do No Harm: Myanmar Trade Sanctions and Human Rights", Northwestern Journal of International human Rights, Vol. 5, issue 2 at 154 .

79 Daley, supra note 75.

80 Baker, supra note 63.

1 Daley, supra note 75. Myanmar's international isolation deepened during 2006 as the authoritarian military government continued to restrict basic rights and freedoms and waged brutal counterinsurgency operations against ethnic minorities. The democratic movement inside the country remained suppressed and human right activists continued to be detained and imprisoned even after this period. See also, Human Rights Watch, Events of 2006 in Burma, (World Report, 2007).

Available at: <http:/hrw. Org/englishwr2k7/docs/2007/01/11/burma14865.htm>, Accessed on 15 November 2011.

2 Sarah H. Cleveland (2001), "Normalization and U.S. Economic Sanctions", 26 Yale Journal of International Law 1 at 7.

83 Ibid.

${ }^{84} \mathrm{Id}$ at $7-8$.

85 Ewing-chow, supra note 78 at 156.

86 Ibid. 
opposition leader, the US enacted the Burmese Freedom and Democracy Act of 2003 (BFDA) which banned the importation of any goods produced, manufactured, grown or assembled in Myanmar. ${ }^{87} \mathrm{EU}$ and Canada also imposed economic and other sanctions against Myanmar. ${ }^{88}$ They had taken unilateral economic sanctions in different occasions.

Despite the economic pressures against Myanmar for two decades, the measures could not be of any good in ensuring respect for human rights in Myanmar. Two decades of economic sanctions have not brought about meaningful human rights improvements and this suggests that there is diminishing prospect for success. ${ }^{89}$

However, as of 2010 some reforms are being introduced which could be the start of a democratic reform in the country. After the 2010 elections, the prodemocracy leader Suu Kyi was released from house arrest. ${ }^{90}$ in 2011 a civilian government was sworn in and introduced some political and economic reforms. ${ }^{91}$ Following such reforms, EU and other western countries have eased trade sanctions. ${ }^{92}$ The country has also been visited by world leaders such as Prime Minister David Cameron ${ }^{93}$ and US President Obama. ${ }^{94}$

87 Id at 157.

88 When Myanmar declined a request by $\mathrm{EU}$ for investigation into its forced labor practices and in response to a complaint by European trade unions, the European Commission for the first time exercised the human rights clause of the European Generalized System of Preferences (GSP) program to terminate Myanmar's GSP trade benefits on industrial exports to the EU. See Cleveland, supra note 82 at 10 . In 1997 the EU revoked Myanmar's benefits under the Generalized System of Preferences which affected 5\% of Myanmar's exports. In 2003 the EU decided to impose new expanded sanctions. See Ewing- Chow, supra note 78 at 159. In 1997, Canada also withdrew General Preferential Tariff benefits from Myanmar and required all Canadian firms trading in Myanmar to get export permits. (See, Human Rights Watch, World Report 1998, at 162).

89 Nyun, supra note 2 at 485.

${ }^{0}$ See Wikipedia, Available at: <http://en.wikipedia.org/wiki/Burma>.

91 Ibid.

92 Suu Kyi calls Further Easing of Burma Sanctions, BBC News, 19 September 2012. Available at: http://www.bbc.co.uk/news/world-asia-19633062dAccessed on October 5, 2012).

93 David Cameron Calls for Burma Sanctions to be Suspended, BBC News, 13 April 2012. Available at: http://www.bbc.co.uk/news/world-asia-17699433 (Accessed on September 15, 2012).

94 US President Obama Hails Burma's 'Remarkable Journey’, BBC News, 19 November 2012. Available at : http://www.bbc.co.uk/news/world-asia-20386066 (Accessed on November 21, 2012). 
What led to the introduction of reforms in Myanmar should further be analyzed. It can, however, be argued that unilateral sanctions for more than two decades had little contribution toward the introduction of reforms in the country. This is because if sanctions had significant effect in bringing such reforms, the country would have responded so early to the trade sanctions that have been in place for more than two decades. Even when it is argued that they had significant contribution, the misery and the human rights violations inflicted upon the people of Myanmar as a result of the trade sanctions makes such measures unappealing and undesirable.

Apart from the inefficacy of unilateral trade measures to induce respect for human rights, the fact that such measures exacerbate human right violations makes the measures unacceptable. As Margaret Doxey rightly argues, for the target governments "survival is all-important and their control of the levers of power, which may actually be enhanced by sanctions, enables them to shift any burden of hardship onto the mass of the people ${ }^{95}$." Hence, unilateral sanctions bring unintended consequences on the population and the consequences of such measures are unbearable for the general public.

For Instance, in Myanmar, sanctions brought the loss of 60,000 jobs in the textile industry alone and a decrease in per capita income from Us \$ 225 in 2004 to US \$ 145 in 2005 thereby exacerbating the suffering of the general population..$^{96}$ The sanctions also resulted in an estimated loss of 40,000 jobs in the garment industry. ${ }^{97}$ Since many of the workers laid off in this industry were women, some of them have been forced into prostitution as a means of livelihood for their families. ${ }^{98}$ Such circumstances clearly expose women for health problems including the risk to life. Generally, the trade sanctions brought about severe consequences on the innocent citizens of Myanmar adversely affecting their human rights to health, life as well as the right to adequate standards of living.

US unilateral trade sanctions against Cuba since the 1960 are also examples for the inefficacy of such measures. ${ }^{99}$ The main reason for such sanctions was the alleged failure of the Cuban government to comply with fundamental rights. However, the sanctions have not brought about the desired result. The unilateral trade sanctions against Cuba by the U.S. have brought about devastating effects on the health and life of the people as well as the economy of the country.

95 Doxey, supra note 1 at 542.

96 Ewing-chow, supra note 78 at 158.

${ }^{97}$ Ibid.

98 Ibid.

99 Doxey, supra note 1 at 539-540. 
U.S. trade sanctions generally led to severe food shortages that caused widespread nutritional deficiencies and disease. ${ }^{100}$ The trade sanctions have also been linked to epidemics of specific diseases, including neurological disorders and blindness caused by poor nutrition. ${ }^{101}$ Such sanctions in different periods have led to shortages of medical supplies which resulted in series of medical crises and heightened levels of infectious diseases. ${ }^{102}$ The sanctions have also brought about increase in food prices which in turn hindered many people from purchasing enough food for living. Hence, many Cubans were deprived of exercising their human rights to health, the right to adequate of standards of living and the right to food as a result of the unilateral economic sanctions imposed against Cuba. Such measures that have unintended humanitarian consequences against innocent citizens are thus hardly appropriate.

\section{Conclusion}

Unilateral trade sanctions as a response to human rights abuses can be challenged from two perspectives: impact and legality under the wTO regime. while the objective of promoting human rights through unilateral trade sanctions may sound positive, it is not the most effective weapon to ensure that repressive governments comply with basic standards of human rights. Many unilateral trade sanctions have done little to force those in power to comply with human rights standards. Even worse, unilateral trade sanctions are often counterproductive because they have unintended consequences on the general population who live in the target country. Unilateral trade sanctions have hurt most the general population than the repressive governments. Hence, apart from the inefficacy of trade measures to induce respect for human rights, the fact that such measures have unintended humanitarian consequences on the public at large render this approach unacceptable.

Unilateral trade sanctions may have a symbolic significance to send a message that the human rights situation in the target country would not be tolerated. in spite of their symbolic significance, however, such measures are

100 Alberto R. Coll, (2007) "Harming Human Rights in the Name of Promoting Them: The Case of the Cuban Embargo",12 UCLA Journal of International Law \& Foreign Affairs 199 at 238-41. As cited in Lee Baker (2010), "The Unintended Consequences of U.S. Export Restrictions on Software and Online Services for American Foreign Policy and Human Rights", Vol. 23, No. 2., Harvard Journal of Law and Technology at 551.

101 Javier H Campos (2004), "The Impact of the U.S. Embargo on Health Care in Cuba: A Clinician's Perspective", 14 Transnational Law and Contemporary Problems 517 at 521 .

102 R. Garfield, \& S. Santana (January 1997) "The Impact of the Economic Crisis and the US Embargo on Health in Cuba", 1 American Journal of Public Health 87 at 1520 . 
usually weak in bringing about tangible human right changes. Constructive engagement is thus more productive to achieve human rights reforms. Imposing unilateral trade sanctions and following a 'wait and see policy' to lift such sanctions until such time that human rights are respected in the country does not appear to be a sound approach.

Moreover, the legality of unilateral trade sanctions under the WTO Agreements has been controversial. While exceptions of some of the WTO Agreements such as GATT Article XX accommodate some human rights, they are applied to address human rights concerns within one's own territory. Article XX of the GATT allows measures to protect human life and health i.e. protection of the human right to life and health. However, its application is limited in the sense that derogation from the WTO rules can be made only to address public concerns within domestic jurisdiction. The WTO rules do not, arguably, authorize countries to take outwardly directed unilateral trade sanctions against target countries. Article XX does not warrant extraterritorial application. Hence, unilateral trade sanctions against target countries on grounds of human rights violations are neither permitted under WTO rules nor effective mechanisms to ensure respect for human rights.

Furthermore, GATT Article XXI and the UN Charter do not authorize unilateral trade sanctions as a weapon to promote human rights. Of course, the security Council can authorize multilateral trade sanctions in order to maintain or restore international peace and security. Article XXI(c) of the GATT also allows WTO members to impose trade sanctions when the security Council calls upon countries for multilateral action which may include trade embargo. However, unilateral trade sanctions are neither covered under Article XXI exception of the GATT nor under the UN Charter.

This is not to suggest that repressive regimes should be given free ride to do whatever they please in the course of their gross violation of human rights. Rather, the task of regulating gross human rights violations would be more appropriate under the United Nations which has the mandate to authorize multilateral trade sanctions against repressive regimes. In fact, even a comprehensive multilateral trade sanction authorized by the UN has unintended consequences and may not also be effective to bring about the desired result. However, the UN can resort to specific sanctions, as it sometimes does, rather than imposing comprehensive multilateral trade sanctions with a view to minimize the cost of such sanctions on the general population, and at the same time to duly exert pressure against the human rights abuses. 


\section{(c) (1) (9) $\Theta$}

This work is licensed under a

Creative Commons

Attribution - Noncommercial - NoDerivs 4.0 License.

To view a copy of the license please see:

http://creativecommons.org/licenses/by-nc-nd/4.0/

This is a download from the BLDS Digital Library on OpenDocs

http://opendocs.ids.ac.uk/opendocs/ 